OPEN ACCESS

Edited by: Banasri Hazra, Jadavpur University, India

Reviewed by: Javad Sharifi-Rad,

Shahid Beheshti University of Medical Sciences, Iran

Prasat Kittakoop,

Chulabhorn Graduate Institute,

Thailand

*Correspondence: Serawit Deyno dserawit@std.must.ac.ug

Specialty section: This article was submitted to

Ethnopharmacology,

a section of the journal

Frontiers in Pharmacology

Received: 21 September 2020 Accepted: 02 December 2020

Published: 25 January 2021

Citation:

Deyno S, Mtewa AG, Hope D, Bazira J, Makonnen $E$ and Alele PE (2021)

Antibacterial Activities of Echinops kebericho Mesfin Tuber Extracts and Isolation of the Most Active Compound, Dehydrocostus Lactone.

Front. Pharmacol. 11:608672. doi: 10.3389/fphar.2020.608672

\section{Antibacterial Activities of Echinops kebericho Mesfin Tuber Extracts and Isolation of the Most Active Compound, Dehydrocostus Lactone}

\author{
Serawit Deyno ${ }^{1,2,3 *}$, Andrew G. Mtewa ${ }^{4}$, Derick Hope ${ }^{5}$, Joel Bazira ${ }^{6}$, Eyasu Makonnen ${ }^{7,8}$ and \\ Paul E. Alele ${ }^{1}$ \\ ${ }^{1}$ Department of Pharmacology, Mbarara University of Science and Technology, Mbarara, Uganda, ${ }^{2}$ Department of \\ Pharmacology, School of Pharmacy, College of Medicine and Health Sciences, Hawassa University, Hawassa, Ethiopia, \\ ${ }^{3}$ Pharmbiotechnology and Traditional Medicine Center of Excellence (PHARMBIOTRAC), Mbarara University of Science and \\ Technology, Mbarara, Uganda, ${ }^{4}$ Chemistry Section, Department of Applied Sciences, Malawi Institute of Technology, Malawi \\ University of Science and Technology, Limbe, Malawi, ${ }^{5}$ MSF Mbarara Research Base, Mbarara University of Science and \\ Technology, Mbarara, Uganda, ${ }^{6}$ Department of Microbiology, Mbarara University of Science and Technology, Mbarara, Uganda, \\ ${ }^{7}$ Center for Innovative Drug Development and Therapeutic Trials for Africa, College of Health Sciences, Addis Ababa University, \\ Addis Ababa University, Addis Ababa, Ethiopia, ${ }^{8}$ Department of Pharmacology and Clinical Pharmacy, College of Health \\ Sciences, Addis Ababa University, Addis Ababa University, Addis Ababa, Ethiopia
}

Echinops kebericho Mesfin is traditionally used for the treatment of various infectious diseases. This study investigated antibacterial activity of the essential oil (EO) and the different fractions of ethanol extract. The most active component was isolated and identified. Isolation and purification was accomplished using chromatographic techniques while identification was done by spectroscopic method. Minimum inhibitory concentration (MIC) was determined using the broth micro-dilution method. In bioactiveguided isolation, percent inhibition was determined using optical density (OD) measurement. The MICs of the essential oil ranged from $78.125 \mu \mathrm{g} / \mathrm{ml}$ to $625 \mu \mathrm{g} / \mathrm{ml}$, and its activity was observed against methicillin-resistant Staphylococcus aureus (MRSA, NCTC 12493). Ethyl acetate fraction showed high activity against MRSA (NCTC 12493), $\mathrm{MIC}=39.075 \mu \mathrm{g} / \mathrm{ml}$ followed by Enterococcus faecalis (ATCC 49532), $\mathrm{MIC}=78.125 \mu \mathrm{g} /$ $\mathrm{ml}$ and was least active against Klebsiella pneumoniae (ATCC 700603), MIC = 1,250 $\mu \mathrm{g} /$ $\mathrm{ml}$. MIC of hexane fraction ranged from $156.2 \mu \mathrm{g} / \mathrm{ml}$ to Escherichia coli (ATCC 49532) to $1,250 \mu \mathrm{g} / \mathrm{ml}$ to $E$. coli (NCTC 11954). The MICs of chloroform fraction ranged from 312.5 to $2500 \mu \mathrm{g} / \mathrm{ml}$; while butanol fraction could be considered pharmacologically inactive as its MIC value was $2,500 \mu \mathrm{g} / \mathrm{ml}$ for all and no activity against E. coli (NCTC 11954). Dehydrocostus lactone was successfully isolated and identified whose MIC was $19.53 \mu \mathrm{g} / \mathrm{ml}$ against MRSA. Dehydrocostus lactone isolated from E. kebericho M. showed noteworthy antibacterial activity which lends support to ethnopharmacological

\footnotetext{
Abbreviations: ATCC, american type culture collection; CLSI, clinical and laboratory standards institute; DCL, Dehydrocostus lactone; DMSO, Dimethyl sulfoxide; EO, Essential oil; MBC, minimum bactericidal concentration; MHB, Muller-Hinton broth; MIC, minimum inhibitory concentration; MRSA, Methicillin-resistant Staphylococcus aureus; NCTC: national collection of type cultures; OD, optical density.
} 
use of the plant. Further optimization should be done to improve its antibacterial activities and pharmacokinetic profile.

Keywords: dehydrocostus lactone, essential oil, minimum inhibitory concentration, resazurin assay, optical density, fractions

\section{INTRODUCTION}

Antimicrobial resistance (AMR) has resulted in the reemergence of infectious diseases challenges as a contemporary global threat to human health with millions of infections and thousands of annual deaths (Holmstrup and Klausen, 2018). AMR is growing at a faster pace than either discovery of new drugs or alternative approaches to tackling it, leaving common infections untreatable (WHO, 2017). With this resurgence worldwide, the search for novel antimicrobials and alternative approaches to tackling the problem is urgently needed. Modification of existing antibiotics, rediscovering antimicrobials, repurposing antimicrobials, combination treatment, looking for untested sources of antibiotics, and searching for compounds found from chemists around the world are potential sources (Schneider et al., 2017). Plant-based compounds have promising potential as novel antimicrobials or adjuvants in modifying existing antimicrobials (da Silva et al., 2017; Salehi et al., 2019a, Salehi et al., 2019b, Salehi et al., 2020; Yang et al., 2018). A recent review demonstrated a selection of 183 compounds from plants and discussed emerging trends in antibacterial drug discovery from plants (Porras et al., 2020).

Among the many secondary plant metabolites, essential oils (EOs) of different plant sources showed noteworthy antibacterial activities (Dorman and Deans, 2000; Artini et al., 2018) and resistance modulatory effect (Hammer et al., 2012). There is renewed research focused on discovering potential novel antibacterial agents and/adjuvants from plants (da Silva et al., 2017). Echinops kebericho Mesfin (Asteraceae) is an endemic medicinal plant used for treatment of various diseases (Alemayehu, 2017). It is used for the management of human and livestock ailments such as wound infections, toothache, tonsillitis, stomachache, gonorrhea, respiratory manifestations, febrile illness, lung tuberculosis, trypanosomiasis, typhoid, typhus, common cold, cancer, colic, cough, scabies, malaria, headache, fumigation during childbirth, and as mosquito repellent (Kloos, 1977; Abebe, 1996; Teklehaymanot et al., 2007; Teklehaymanot and Giday, 2007; Abera, 2014; Bitew and Hymete, 2019; Megersa et al., 2019). In veterinary practice, the tubers are powdered and mixed with water and given for black leg disease, respiratory manifestations, liver disease, and skin infections (Yigezu et al., 2014). It is used as a water decoction, infusion, smoke inhaled, orally chewed, and topical sprayed to the affected area (Kloos, 1977; Teklehaymanot et al., 2007; Teklehaymanot and Giday, 2007; Abera, 2014). Its safety was established in animal model (Deyno et al., 2020a) and previous studies revealed the presence of flavonoids, alkaloids, triterpenoids, resins, saponins, and steroids (Abegaz et al., 1991; Toma et al., 2015) and dehydrocostus lactone is also identified as a main component of the EOs (Abegaz et al., 1991; Hymete and Afifi, 1997; Tariku et al., 2011; Ivana, 2015).
The extracts of E. kebericho $M$. exhibited a wide range of pharmacological effects including anti-helminthic, antibacterial, antifungal, antidiarrheal, anti-spasmolytic and antimalarial activities. Methanolic tuber extract and EO showed relatively moderate antimicrobial activities (Belay et al., 2011; Ameya et al., 2016). Antibacterial activities from crude extracts (Desta, 1993; Ashebir and Ashenafi, 1999; Ameya et al., 2016) and EOs (Belay et al., 2011) were reported. Ivan reported activity against Mycobacterium smegmatis and significant antimicrobial resistance modulatory effects (Ivana, 2015). Noteworthy activities were also reported against fungi (Aspergillus flavus and Candida albicans) (Ameya et al., 2016), malaria parasite (Plasmodium berghei) (Toma et al., 2015), Leishmania (Tariku et al., 2011), earthworm (Hymete and Kidane, 1991), Trypanosoma (Abdeta, 2016), EO produced a dose-dependent mosquito repellent activity (Jemberie et al., 2016), and moderate larvicidal activity (Debella et al., 2007).

However, the antibacterial activity against different multidrug-resistant strains and various solvent fractions have not yet been studied. The spectrum of activity and the most active component of the extract were not elucidated. Herein, we have determined the antibacterial activity of EOs, and fractions of crude extract to eight strains belonging to five species of bacteria. We have isolated the most active compound, identified and determined its activity.

\section{METHODS AND MATERIALS}

\section{Extraction of the Plant Material}

Fresh plant tuber was collected from Andracha woreda, Sheka zone, Southwest Ethiopia. Details of the collection procedure and identification of specimen and deposited Herbarium were previously described (Deyno et al., 2020a). The tuber was rinsed with running water to remove dirt materials and then air-dried in a shaded place away from Sun light. In four cycles, five hundred grams of the plant material was soaked with $2 \mathrm{~L}$ of ethanol for $48 \mathrm{~h}$ under agitation. Pounded plant material was dissolved in water in $1 / 5(\mathrm{w} / \mathrm{v})$ ratio in a round bottom glass flask and subjected to hydro-distillation for $3 \mathrm{~h}$ using the Clevenger type apparatus. The EO was collected, and the volume and weight were measured. The ethanol extract was evaporated on rotary evaporator and dried.

\section{Separation and Isolation}

The dried extract was soaked in distilled water in a separatory funnel where an equal volume of hexane was added, shaken carefully, and allowed to stand until two layers were formed. The hexane layer was separated and the process was repeated three times. Chloroform, ethyl acetate and n-butanol fractions were prepared following the same procedure. 
Gradient solvent systems (non-polar to highly polar solvent system) were prepared and tested for best separation of various organic compounds. A column was packed with silica gel that was encountered slowly from the top with mobile phase. When the column was ready, the sample was loaded inside the top of the column. The column was separated from the incoming mobile phase by a thin layer of cotton to prevent the disturbance of the column by an influx of the mobile phase. The mobile solvent was then allowed to flow down through the column.

Weighed dried residue of the ethyl acetate fraction was adsorbed to silica gel (Merck, high-purity grade, pore size $60 \AA, 230-400$ mesh ASTM) and separated on a column (300 mm height $\times 22.5 \mathrm{~mm}$ diameter). The elution was performed starting from hexane: ethyl acetate (10:0, 10:1, 5: $1,1: 1,1: 5,1: 10)$ followed by mixture of ethyl acetate: methanol $(10: 0,10: 1,5: 1,1: 1,1: 5,1: 10,0: 10)$. Fractions collected were analyzed using thin-layer chromatography (TLC) with the help of capillary tube from the lower edge of the TLC plate, and plate is kept in a developing chamber containing suitable solvent system for specific time until the developing solvent reaches the marked edge of the TLC plate. The plate was taken out from the developing chamber, dried and the solvent front was marked by lead pencil. Compound bands/spots visualized on TLC by visual detection, under UV light (254 $\mathrm{nm}$ and 360 ), in iodine chamber and using spray reagent ( $30 \%$ sulfuric acid) for the presence of specific compounds. The visualized spots were marked and the Rf (retention factor) value of each spot was calculated.

\section{Spectroscopic Analysis}

${ }^{1} \mathrm{H}$ and ${ }^{13} \mathrm{C}$ NMR spectra were recorded on Bruker Avance DMX400 FT-NMR spectrometer using TMS as internal standard, at the Department of Chemistry, Faculty of Science, Addis Ababa University, Ethiopia. Distortionless enhancement by polarization transfer (DEPT) spectra was also acquired by Bruker.

The GC-MS analysis was conducted using Agilent Technologies. The analysis condition was; chromatographic system (7890B GC), detector (5977A MS), and column (DB$5 \mathrm{MS}, 30 \mathrm{~m} \times 0.25 \mathrm{~mm} \times 0.25 \mu \mathrm{m})$. The GC experimental condition was; inlet temperature $\left(260{ }^{\circ} \mathrm{C}\right)$, injection volume $(1 \mu \mathrm{L})$, split ratio (100). The carrier gas was He with a column flow rate of $1 \mathrm{ml} / \mathrm{min}$. The oven temperature was $40{ }^{\circ} \mathrm{C}$ hold for $3 \mathrm{~min}$, then $4{ }^{\circ} \mathrm{C} / \mathrm{min}$ to $80^{\circ} \mathrm{C}$ hold for $7 \mathrm{~min}$, by $4{ }^{\circ} \mathrm{C} / \mathrm{min}$ to $170{ }^{\circ} \mathrm{C}$ hold for $3 \mathrm{~min}$, at $6^{\circ} \mathrm{C} / \mathrm{min}$ to $230^{\circ} \mathrm{C}$ hold for $4 \mathrm{~min}$ finally, by $10^{\circ} \mathrm{C} / \mathrm{min}$ to $270^{\circ} \mathrm{C}$. MS experimental conditions were; ionization mode (EI), EMV mode (gain Factor), gain factor $(1)$, transfer line temperature $\left(280{ }^{\circ} \mathrm{C}\right)$, ion source temp $\left(230^{\circ} \mathrm{C}\right)$, Quad temp $\left(150{ }^{\circ} \mathrm{C}\right)$, solvent delay $(3 \mathrm{~min})$, and acquisition mode (scan, 50-550 amu). The compounds were identified by the use of a combination of mass spectrum database search (IMS Terpene Library, NIST MS database), relative retention time (ESO database of EOs) and comparison of mass spectra. Quantitative analysis was performed by peak area normalization (\%) measurements (TIC, total ion count) of GC-MS chromatograms.

\section{Microorganisms}

The bacteria strains used were Staphylococcus aureus (ATCC 29213), S. aureus (MRSA) (NCTC 12493), Enterococcus faecalis (ATCC 29212), Enterococcus faecalis (ATCC 49532), Pseudomonas aeruginosa (ATCC 27853), Escherichia coli (ATCC 25922), E. coli (NCTC 11954), and Klebsiella pneumoniae (ATCC700603).

Preparation, Storage and Testing Reagents Resazurin was prepared in a concentration of $0.015 \%$ by dissolving $0.015 \mathrm{~g}$ in $100 \mathrm{ml}$ of PBS, vortexed, sterilized by microfiltration and stored at $4{ }^{\circ} \mathrm{C}$ (Elshikh et al., 2016).

\section{Preparation and Serial Dilution of the Extract Solution}

Essential oils and fractions/extracts were dissolved in dimethyl sulfoxide (DMSO) for antibacterial activity assay. The final concentration of DMSO was less than or equal to $2 \%$. The stock solution of the extract prepared was $5 \mathrm{mg} / \mathrm{ml}$ and was serially diluted with broth. A stock concentration of $128 \mu \mathrm{g} / \mathrm{ml}$ of ciprofloxacin was also prepared and serially diluted.

\section{Preparation and Standardization of Inoculum}

The inocula were prepared following the Clinical and Laboratory Standards Institute (CLSI) recommendation and standardized to $0.5 \mathrm{McF}$ arland turbidity standards equivalent to $1 \times 10^{8} \mathrm{CFU} / \mathrm{ml}$ using inoculum densitometers. Then it was further diluted to obtain the desired cell density of $5 \times 10^{5} \mathrm{CFU} / \mathrm{ml}$ (Patel et al., 2015). Briefly, an equivalent of $0.5 \mathrm{McF}$ arland suspensions $(1 \times$ $10^{8} \mathrm{CFU} / \mathrm{ml}$ ) inoculum was prepared and then diluted 1:20 to yield $5 \times 10^{6} \mathrm{CFU} / \mathrm{ml}$ using saline media. Then, $0.02 \mathrm{ml}$ of this suspension was inoculated into $0.18 \mathrm{ml}$ of broth yielding a final concentration of bacteria approximately equal to $5 \times 10^{5} \mathrm{CFU} / \mathrm{ml}$.

\section{Minimum Inhibitory Concentration Determination}

Minimum inhibitory concentration (MIC) was determined using the broth micro-dilution method (Eloff, 1998). CLSI guideline procedures and safety precautions were strictly followed (CLSI, 2018). The 96-well plates were dispensed first with $100 \mu \mathrm{L} \mathrm{MHB}$ then EO, the fractions and isolated compound of $100 \mu \mathrm{L}$ were added in the first well and serially diluted up to the 10th well. The excess $100 \mu \mathrm{L}$ was removed from the 10 th well. Finally, $100 \mu \mathrm{L}$ of MHB mixed with inoculum was added from the first to the 11th well. The 11th well contains the broth without the intervention, sterility control, while the $12^{\text {th }}$ well contains broth without inoculum and intervention, fertility control. The final volume in each well was $200 \mu \mathrm{L}$.

The bacteria were incubated for $24 \mathrm{~h}$ at $35-37^{\circ} \mathrm{C}$. The MIC of DMSO was also evaluated as negative control while ciprofloxacin was a positive control. Prior to use, the broth was checked for sterility and fertility. Microbial growth was indicated by an irreversible change in color from the blue of resazurin to pink 


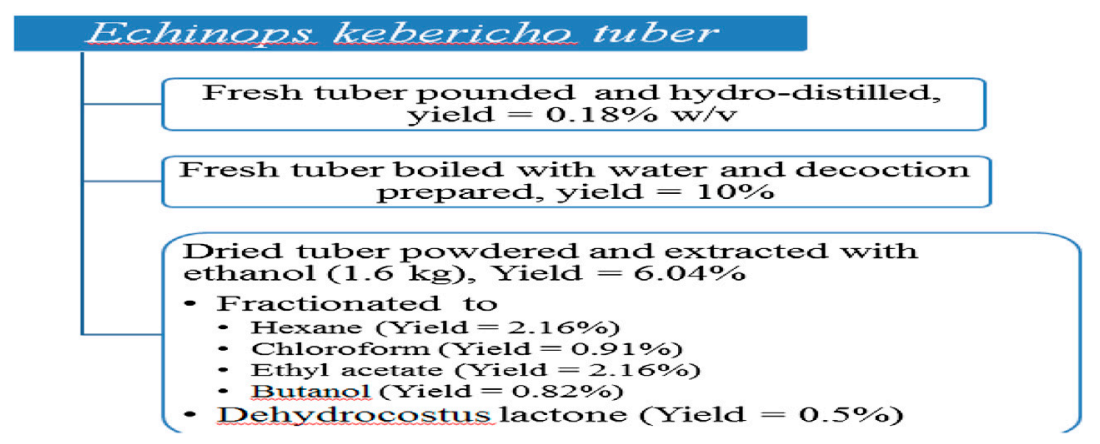

FIGURE 1 | Yields of pounded hydrodistilled and decoction of fresh tuber as well as those of ethanol extract together with its fractions.

TABLE 1 | Results of preliminary phytochemical identification tests.

\begin{tabular}{|c|c|c|c|c|c|}
\hline $\begin{array}{l}\text { Extract/fractions test } \\
\text { type }\end{array}$ & nol extract & Hexane fraction & Chloroform fraction & $\begin{array}{c}\text { Ethyl acetate } \\
\text { fraction }\end{array}$ & Butanol fraction \\
\hline
\end{tabular}

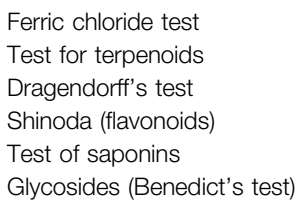

+
+
-
-
-
+

$\begin{array}{ll}+ & - \\ + & - \\ - & - \\ - & - \\ - & - \\ - & +\end{array}$

resofurin after $20 \mathrm{~h}$ of incubation. Minimum bactericidal concentration (MBC) was determined by re-culturing from four well plates which have concentration equal to or greater than the MIC. The plates on which bacterial growth started to be seen were considered MBC. Measurement of optical density (OD) at $620 \mathrm{~nm}$ were taken at $0,2,4,18$ and $24 \mathrm{~h}$. Graph of time vs. absorbance (OD) vs. concentration was plotted at time $0,2,4,18$, and $20 \mathrm{~h}$. The plot at $18 \mathrm{~h}$ and $20 \mathrm{~h}$ were compared with resazurin assay value for MIC.

\section{Bioactivity-Guided Isolation}

Collected fractions from column chromatography were regrouped based on the TLC plate's profile reducing the fractions from 67 to 20 . These twenty fractions were dried and dissolved in DMSO and antibacterial activity was determined at $0.25 \mathrm{mg} / \mathrm{ml}$ concentration to identify the most active fraction. Percent inhibition was calculated using the formula given below for a comparison of fractions activity.

\section{RESULTS}

\section{Essential Oil Components and Fractions of Ethanol Extract of E. kebericho Tuber Yield}

The yield of the EO was $0.18 \% \mathrm{w} / \mathrm{v}$ of dried weight. The fractionation of $96.7 \mathrm{~g}$ of ethanol extract yielded $34.5 \mathrm{~g}$ hexane, $34.6 \mathrm{~g}$ ethyl acetate, $14.5 \mathrm{~g}$ chloroform, and $13.1 \mathrm{~g}$ butanol fractions. The yield of ethanol extract was $6.04 \%$, while that of ethyl acetate residual extract was $2.16 \%$. Finally the yield of the isolated dehydrocostus lactone was $0.5 \%$ (Figure 1).

\section{Phytochemical Screening}

The results of preliminary phytochemical screening on ethanol extract as well as its hexane, chloroform, ethyl acetate, and butanol fractions showed presence of different constituents. The major component was terpinoids as summarized in Table $\mathbf{1 .}$

\section{Components of Essential Oil}

Hydrodistillation of the tubers of E. kebericho M. yielded light yellowish oil $(0.18 \%$ v/w). Forty-two different EOs were detected; their molecular formula, retention time, and percentage distributions (peak area \%) are presented in Table 2. The isoshyobunone was the most abundant compound (12.64\%) detected followed by modephene (10.41\%), isocomene $(8.42 \%$ 0 , $\beta$-phellandrene (7.00\%), $\alpha$-pinene $(6.96 \%)$, DCL (6.52\%), $\beta$-pinene (6.29\%), and $\beta$-isocomene $(6.08 \%)$.

\section{Column Chromatography Isolation and TLC Fingerprints}

Ethyl acetate fraction of $30 \mathrm{~g}$ chromatographed on column gave sixty-seven fractions which were analyzed on TLC plates and pooled based on their fingerprints. Based on their TLC profile, the 67 column fractions were regrouped in 20 fractions. Physical appearance of the fractions F1-5 were oily, F6-8 creamy, F9-14 adhesive mucilage and F15-20 were dry solid.

The TLC profiles of the first four fractions collected were presented in Figure 2. Hexane: chloroform: ethyl acetate (6:3:1) solvent mixture did not provide effective separation while hexane: chloroform: ethyl acetate $(7: 2: 1)$ did the best separation. The fractions were stored in refrigerator at $2{ }^{\circ} \mathrm{C}$ in a refrigerator, and 
TABLE 2 | Chemical Composition [\% peak area] of EO of E. kebericho obtained by hydrodistillation and identified by GC/MS analysis.

\begin{tabular}{|c|c|c|c|c|}
\hline No & Name & Formula & Rt & $\%$ Area \\
\hline 1 & Bicyclo (3.1.0)hex-2-ene 2-methyl-5-(1-methylethyl) & $\mathrm{C} 10 \mathrm{H} 16$ & 10.19 & 0.13 \\
\hline 2 & a-pinene & $\mathrm{C} 10 \mathrm{H} 16$ & 10.49 & 6.96 \\
\hline 3 & Camphene & $\mathrm{C} 10 \mathrm{H} 16$ & 11.08 & 0.26 \\
\hline 4 & Bicyclo (3.1.0)hexane 4 methylene-1-(1-methyethyl) & $\mathrm{C} 10 \mathrm{H} 16$ & 12.04 & 1.88 \\
\hline 5 & $\beta$-pinene & $\mathrm{C} 10 \mathrm{H} 16$ & 12.24 & 6.29 \\
\hline 6 & $\beta$-myrcene & $\mathrm{C} 10 \mathrm{H} 16$ & 12.73 & 0.37 \\
\hline 7 & a-phellandrene & $\mathrm{C} 10 \mathrm{H} 16$ & 13.36 & 0.44 \\
\hline 8 & a-cymene & $\mathrm{C} 10 \mathrm{H} 16$ & 14.20 & 0.31 \\
\hline 9 & $\beta$-phellandrene & $\mathrm{C} 10 \mathrm{H} 16$ & 14.51 & 7.00 \\
\hline 10 & trans- $\beta$-ocimene & $\mathrm{C} 10 \mathrm{H} 16$ & 15.30 & 0.34 \\
\hline 11 & trans-verbenol & $\mathrm{C} 10 \mathrm{H} 16 \mathrm{O}$ & 22.17 & 1.08 \\
\hline 12 & Endo-borneol & $\mathrm{C} 10 \mathrm{H} 18 \mathrm{O}$ & 23.78 & 0.42 \\
\hline 13 & Terpinen-4-ol & $\mathrm{C} 10 \mathrm{H} 18 \mathrm{O}$ & 24.27 & 0.19 \\
\hline 14 & (-)-Myrtenol & $\mathrm{C} 10 \mathrm{H} 16 \mathrm{O}$ & 25.21 & 0.13 \\
\hline 15 & Bornyl acetate & $\mathrm{C} 12 \mathrm{H} 2 \mathrm{OO} 2$ & 29.48 & 1.85 \\
\hline 16 & Silphiperfol-5ene & $\mathrm{C} 15 \mathrm{H} 24$ & 31.09 & 0.83 \\
\hline 17 & a-guaiene & $\mathrm{C} 15 \mathrm{H} 24$ & 31.94 & 3.29 \\
\hline 18 & 7-Epi-silphiperfol-5ene & $\mathrm{C} 15 \mathrm{H} 24$ & 33.06 & 0.13 \\
\hline 19 & Modephene & $\mathrm{C} 15 \mathrm{H} 24$ & 33.39 & 10.41 \\
\hline 20 & Isocomene & $\mathrm{C} 15 \mathrm{H} 24$ & 33.63 & 8.42 \\
\hline 21 & $\beta$-elemen & $\mathrm{C} 15 \mathrm{H} 24$ & 33.72 & 2.46 \\
\hline 22 & Methyleugenol & $\mathrm{C} 11 \mathrm{H} 14 \mathrm{O} 2$ & 34.22 & 1.36 \\
\hline 23 & $(\mathrm{~A} \pm)$ - $\beta$-isocomene & $\mathrm{C} 15 \mathrm{H} 24$ & 34.45 & 6.08 \\
\hline 24 & Caryophyllene & $\mathrm{C} 15 \mathrm{H} 24$ & 34.76 & 3.13 \\
\hline 25 & Humulene & $\mathrm{C} 15 \mathrm{H} 24$ & 36.01 & 1.50 \\
\hline 26 & Aromandendrene & $\mathrm{C} 15 \mathrm{H} 24$ & 36.16 & 1.17 \\
\hline 27 & trans-beta-ionone & $\mathrm{C} 13 \mathrm{HH} 20 \mathrm{O}$ & 36.88 & 0.39 \\
\hline 28 & Bicyclogermacren & $\mathrm{C} 15 \mathrm{H} 24$ & 37.37 & 0.40 \\
\hline 29 & Cubebol & $\mathrm{C} 15 \mathrm{H} 260$ & 37.50 & 0.68 \\
\hline 30 & $\gamma$-cadinene & $\mathrm{C} 15 \mathrm{H} 24$ & 37.99 & 0.41 \\
\hline 31 & Isoshyobunone & $\mathrm{C} 15 \mathrm{H} 24 \mathrm{O}$ & 38.15 & 12.64 \\
\hline 32 & Germacrene-D-4-ol & $\mathrm{C} 15 \mathrm{H} 26 \mathrm{O}$ & 40.09 & 5.25 \\
\hline 33 & Caryophyllene oxide & $\mathrm{C} 15 \mathrm{H} 24 \mathrm{O}$ & 40.19 & 2.45 \\
\hline 34 & Cyclopenta(c) pentalen-3 (3aH)-one, octahydro-1,2,3a,6tetramethyl & $\mathrm{C} 15 \mathrm{H} 24 \mathrm{O}$ & 40.64 & 0.67 \\
\hline 35 & a-cadinol & $\mathrm{C} 15 \mathrm{H} 26 \mathrm{O}$ & 42.40 & 0.71 \\
\hline 36 & Aromadendrene oxide-(1) & $\mathrm{C} 15 \mathrm{H} 24 \mathrm{O}$ & 42.51 & 1.24 \\
\hline 37 & Pentadecanal & $\mathrm{C} 15 \mathrm{H} 300$ & 44.22 & 0.23 \\
\hline 38 & Costol & $\mathrm{C} 15 \mathrm{H} 24 \mathrm{O}$ & 45.61 & 0.50 \\
\hline 39 & Dihydrodehydrocostus lactone & $\mathrm{C} 15 \mathrm{H} 20 \mathrm{O} 2$ & 50.75 & 0.42 \\
\hline 40 & Dehydrocostuslactone & $\mathrm{C} 15 \mathrm{H} 18 \mathrm{O} 2$ & 52.04 & 6.52 \\
\hline 41 & Heptacosane & $\mathrm{C} 27 \mathrm{H} 56$ & 56.67 & 0.57 \\
\hline 42 & Octacosane & $\mathrm{C} 28 \mathrm{H} 58$ & 62.06 & 0.49 \\
\hline
\end{tabular}

the following day crystal was formed in fractions 1-8. These fractions were separated from the remaining mixture by careful decantation and dried separately after washing gently with hexane for the purification. TLC profiles for each were examined, and those with the same profile were combined. The isolated compound was a white crystal with a melting point of $59-62^{\circ} \mathrm{C}$ and dissolved in ethanol, hexane, and acetone but poorly dissolved in water. Its retention time was $20 \mathrm{~min}$ in hexane: chloroform: ethyl acetate (7:2:1) solvent system which gave a retention index of 0.614 (Figure 2). The yield of the crystal isolated was $0.5 \%$.

The UV spectrum of the isolated compound shows a clean single peak at 100\% abundance, signifying the purity (Figure 3).

The MS of the isolated compound gave $[\mathrm{M}]+=230.1$. Analysis of GC-MS and search in libraries identified the compound to be dehydrocostus lactone (Figure 4).
HNMR spectra of the isolated compound was; HNMR (DMSO-d, $500 \mathrm{MHz}): 1.35(1 \mathrm{H}, \mathrm{m}), 1.77-1.94(2 \mathrm{H}, \mathrm{m}), 2.15$ $(1 \mathrm{H}, \mathrm{m}), 2.26(1 \mathrm{H}, \mathrm{m}), 2.42(2 \mathrm{H}, \mathrm{m}), 2.47(1 \mathrm{H}, \mathrm{m}), 2.88(1 \mathrm{H}, \mathrm{m})$, $2.97(2 \mathrm{H}, \mathrm{m}), 3.95(1 \mathrm{H}, \mathrm{t}), 4.76(1 \mathrm{H}, \mathrm{s}), 4.88(1 \mathrm{H}, \mathrm{s}), 4.99(1 \mathrm{H}, \mathrm{s})$, $5.10(1 \mathrm{H}, \mathrm{s}), 5.64(1 \mathrm{H}, \mathrm{d}), 6.04(1 \mathrm{H}, \mathrm{d})$. Solvent peak was at 2.5 and water residues due to the solvent at 3.33 (Figure 5).

The 13C NMR spectra of the isolated compound was (DMSOd, $400 \mathrm{MHz}$ ): d30.1 t, $30.9 \mathrm{t}, 32.7 \mathrm{t}, 36.2 \mathrm{t}, 44.5,47.1,51.9 \mathrm{~d}$, 85.3 days, $108.7 \mathrm{t}, \quad 112.3 \mathrm{t}, 120.4 \mathrm{t}, 140.2 \mathrm{~s}, 150.2 \mathrm{~s}, 152.5 \mathrm{~s}$, $170.0 \mathrm{~s}$. The solvent peak was at 39.5 (Figure 6).

The DEPT in comparison with ${ }^{13} \mathrm{C}$ NMR (Figure 6) showed the molecule comprises seven methylenes, four methines, and four nonprotonated carbons (Figure 7).

The spectroscopic data given above and the melting point $\left(61-62^{\circ} \mathrm{C}\right)$ confirm that the compound dehydrocostus lactone was successfully isolated and purified which matched with 


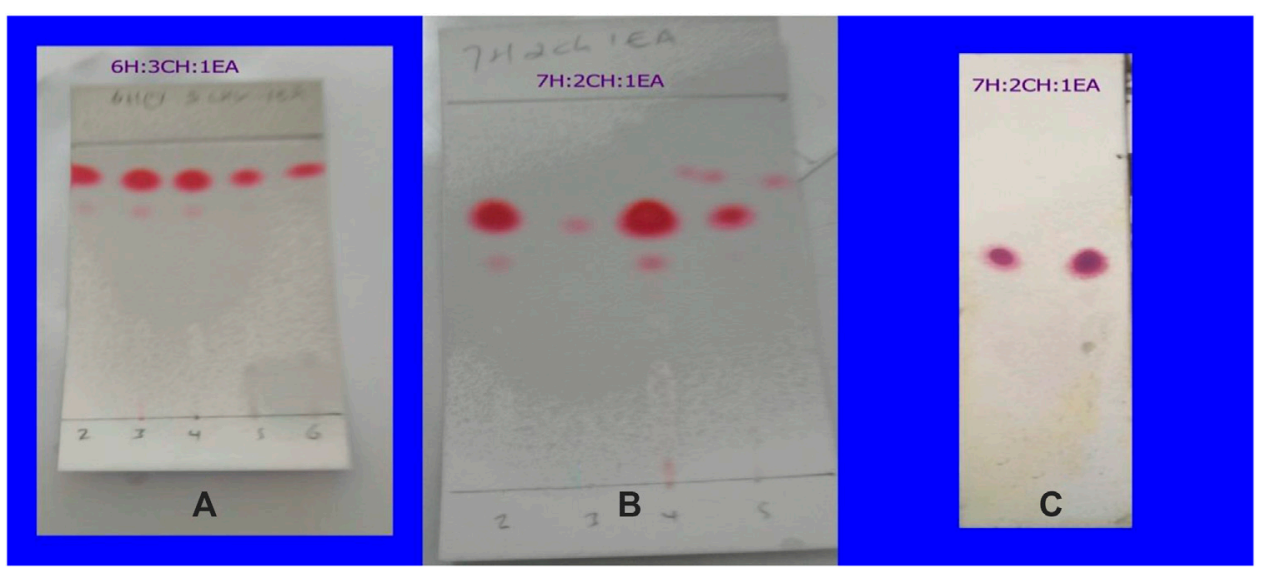

FIGURE 2 | The TLC fingerprint of the first six fractions collected from the column chromatography in different solvent system (A,B) and the isolated compound from fractions $1-8$ by decantation after crystallization (C).

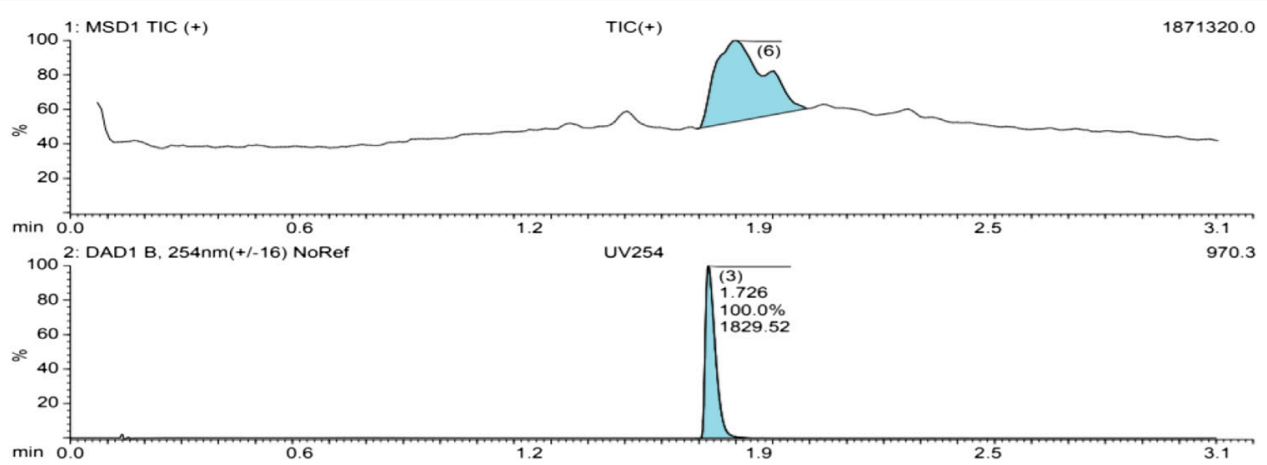

FIGURE 3 | The Total ionic count and UV spectra of an isolated compound.

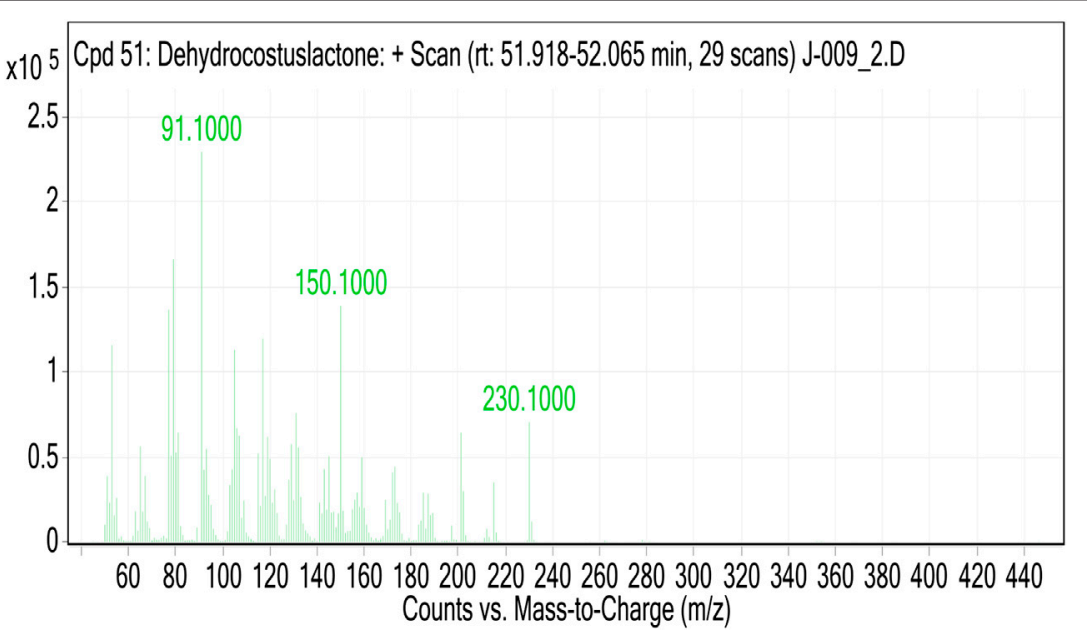

FIGURE 4 | The mass-spectrum of an isolated compound. 


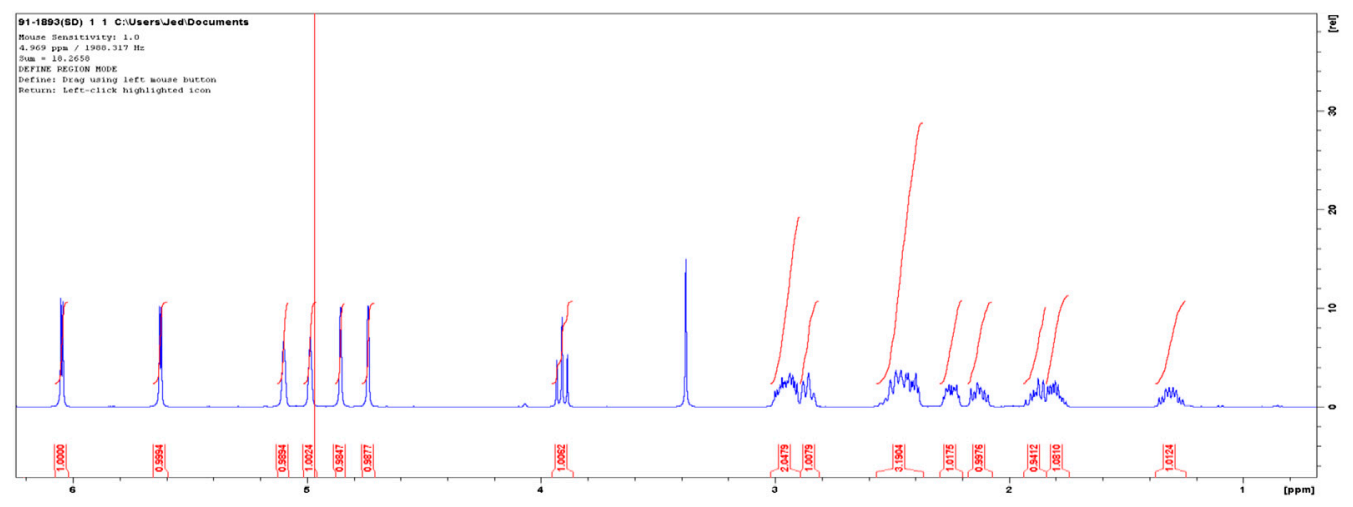

FIGURE 5 | The HNMR spectra of an isolated compound.

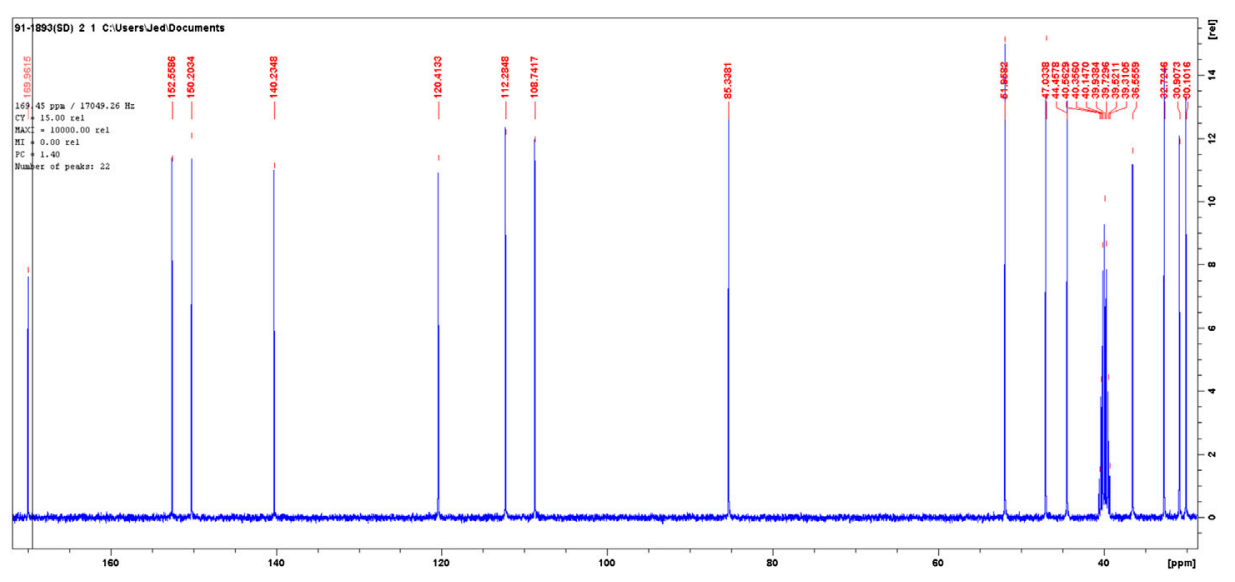

FIGURE 6 | The ${ }^{13} \mathrm{C}$ NMR spectra of isolated compound.

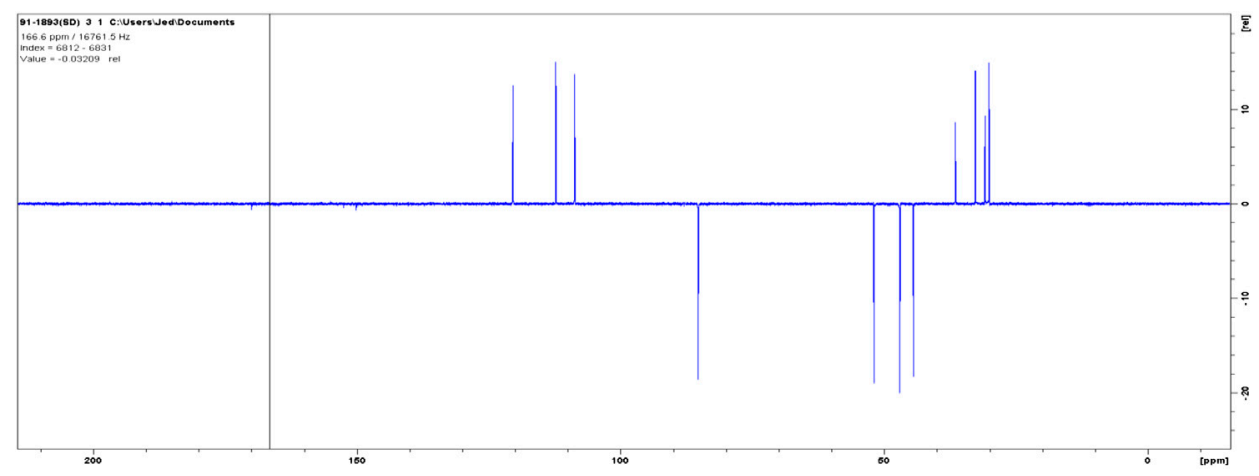

FIGURE 7 | The DEPT NMR spectra of an isolated compound. 


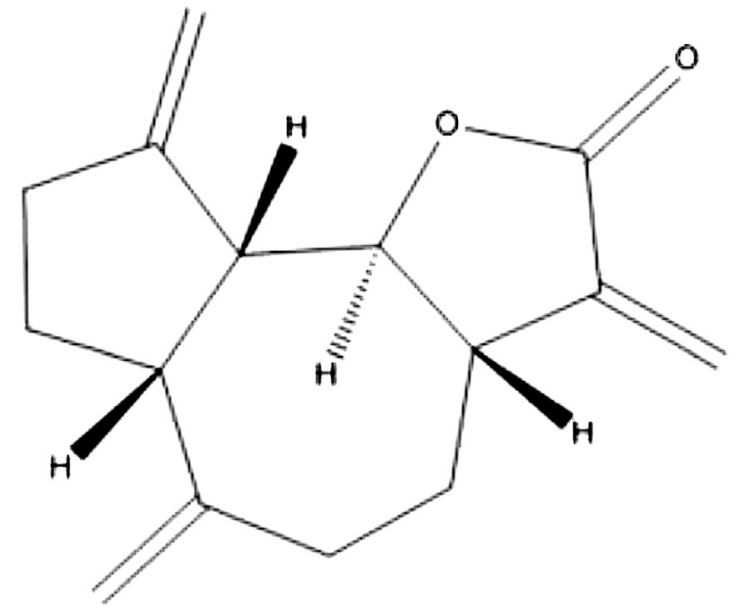

FIGURE 8 | The structural formula of dehydrocostus lactone. pneumonia (ATCC 700603), P. aeuroginosa, ATCC 27853, and E. coli (ATCC 25922). The MIC value of the EO ranged from 78.125 to $625 \mu \mathrm{g} / \mathrm{ml}$. The $\mathrm{MBC}$ value ranged from 0.1562 to $2.5 \mathrm{mg} / \mathrm{ml}$. Sensitivity to EO varied even among strains of the same species. DMSO did not show inhibition at concentration used for dissolving (2\%) and its MIC value ranged $12.5-25 \% \mathrm{w} / \mathrm{v}$ (Table 3).

\section{Effect of Fractions of Ethanol Extract of $E$. kebericho Tuber on the Bacterial Strains}

Of all fractions tested, ethyl acetate fraction showed highest activity followed by hexane fraction, and the butanol fraction showed the least activity of all. MRSA was the most susceptible followed by E. fecalis (ATCC 49532); while E. coli (NCTC 11954) was the most resistant strains among the tested strains. No bactericidal activity was observed against E. coli (NCTC 11954) in the tested concentration range (Table 4).

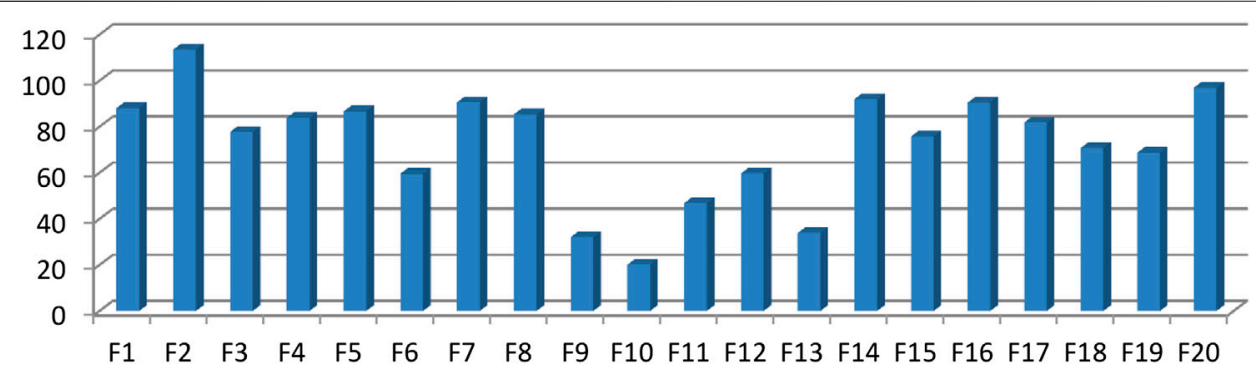

FIGURE 9 | Percent growth inhibition of MRSA strains treated with different column chromatography fractions.

literature (Taniguchi et al., 1995; Lee et al., 2014). The structural formula of the isolated compound was given in Figure 8.

\section{Effect of Essential Oil of E. kebericho M. Tuber on the Bacterial Strains}

Moderate antibacterial activity of the EO was observed against the tested strains. The activity against methicillin resistant $S$. aureus was the highest; while least antibacterial activity was observed against S. aureus (ATCC 29213), E. fecalis (ATCC 49532), K.

\section{Bioactivity-Guided Isolation and} Antibacterial Activity of Isolated Compound The bioactivity guided isolation showed fraction two (F-2) as the most active component of the twenty fractions as determined using optical density measurement (OD) measurement. Figure 9 depicted percent growth inhibition of each fraction as determined by OD measurement.

Fraction two was most active component with MIC = $19.53 \mu \mathrm{g} / \mathrm{ml}$ other fractions were less active and is not single component as illustrated with TLC profile. The

TABLE 3 | Mean Inhibitory and bactericidal concentration of E.kebericho EO against bacteria.

\begin{tabular}{|c|c|c|c|c|c|}
\hline & \multirow[t]{2}{*}{ Microorganisms } & \multicolumn{2}{|c|}{ Essential oil } & \multirow{2}{*}{$\frac{\text { Ciprofloxacillin }}{\text { MIC }(\mu \mathrm{g} / \mathrm{ml})}$} & \multirow{2}{*}{$\frac{\text { DMSO }}{\text { MIC (\% W/V) }}$} \\
\hline & & MIC ( $\mu \mathrm{g} / \mathrm{ml})$ & MBC $(\mu \mathrm{g} / \mathrm{ml})$ & & \\
\hline 1 & S. aureus, ATCC29213 & 625 & 1,250 & 0.5 & 12.5 \\
\hline 2 & S. aureus (MRSA), NCTC 12493 & 78.125 & 156.2 & 4 & 12.5 \\
\hline 3 & E. fecalis, ATCC 29212 & 156.2 & 156.2 & 2 & 12.5 \\
\hline 4 & E. fecalis, ATCC 49532 & 625 & 1,250 & 4 & 12.5 \\
\hline 5 & K. pneumonia, ATCC 700603 & 625 & 2,500 & 8 & 25 \\
\hline 6 & E. coli, ATCC 25922 & 625 & 1,250 & 4 & 25 \\
\hline 7 & E. coli, NCTC 11954 & 312.5 & 625 & 8 & 25 \\
\hline 8 & P. euroginosa, ATCC 27853 & 625 & 1,250 & 1 & 12.5 \\
\hline
\end{tabular}


TABLE 4 | Mean Inhibitory and bactericidal concentrations of Echinops kebericho fractions against bacterial species.

\begin{tabular}{|c|c|c|c|c|c|c|c|c|c|}
\hline \multirow{2}{*}{\multicolumn{2}{|c|}{ Microorganisms }} & \multicolumn{2}{|c|}{ Hexane fraction } & \multicolumn{2}{|c|}{ Ethyl acetate fraction } & \multicolumn{2}{|c|}{ Chloroform fraction } & \multicolumn{2}{|c|}{ Butanol fraction } \\
\hline & & MIC ( $\mu \mathrm{g} / \mathrm{ml})$ & MBC $(\mu \mathrm{g} / \mathrm{ml})$ & MIC ( $\mu \mathrm{g} / \mathrm{ml})$ & MBC $(\mu \mathrm{g} / \mathrm{ml})$ & MIC ( $\mu \mathrm{g} / \mathrm{ml})$ & $\operatorname{MBC}(\mu \mathrm{g} / \mathrm{ml})$ & MIC ( $\mu \mathrm{g} / \mathrm{ml})$ & MBC $(\mu \mathrm{g} / \mathrm{ml})$ \\
\hline 1 & S. aureus, ATCC29213 & 625 & 1,250 & 312.5 & - & 2,500 & - & 2,500 & - \\
\hline 2 & S. aureus, NCTC 12493 & 625 & 625 & 039.075 & 78.125 & 312.5 & 625 & 2,500 & - \\
\hline 3 & E. fecalis, ATCC 29212 & 625 & 1,250 & 156.2 & 312.5 & 2,500 & - & 2,500 & - \\
\hline 4 & E. fecalis, ATCC 49532 & 156.2 & 625 & 78.125 & 156.2 & 1,250 & - & 2,500 & - \\
\hline 5 & K. pneumonia, ATCC 700603 & 625 & 1,250 & 1,250 & - & 2,500 & - & 2,500 & - \\
\hline 6 & E. coli, ATCC 25922 & 312.5 & 625 & 312.5 & 625 & 1,250 & - & 2,500 & - \\
\hline 7 & E. coli, NCTC 11954 & 1,250 & - & 625 & - & 2,500 & - & - & - \\
\hline 8 & P. euroginosa, ATCC 27853 & 312.5 & 1,250 & 312.5 & 625 & 2,500 & - & 2,500 & - \\
\hline
\end{tabular}

MIC, minimum inhibitory concentration; MBC, minimum bactericidal concentration.
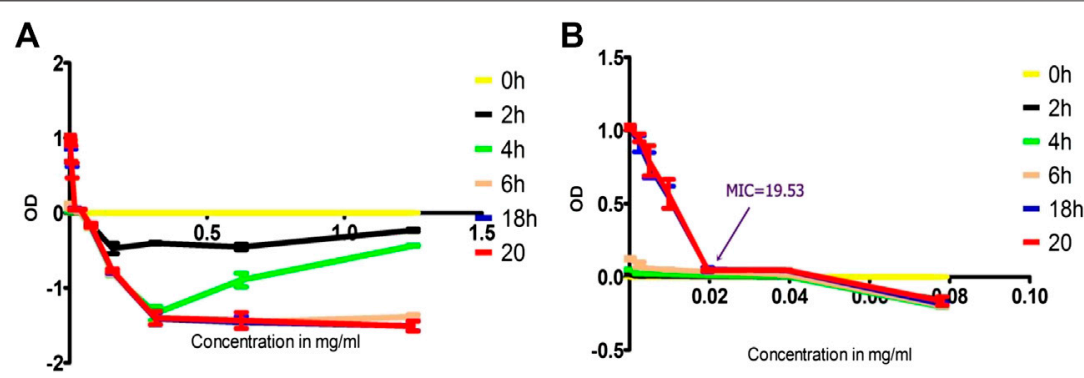

FIGURE 10 | Time-kill analysis using OD values of treated MRSA with isolated compound as function of concentration, (A) throughout the range of concentration treated (1.25 to $0.002441 \mathrm{mg} / \mathrm{ml})$ and $\mathbf{( B )}$ concentration range truncated to values of 0.078125 to 0.002441$)$ to show $\mathrm{MIC}$ values clearly.
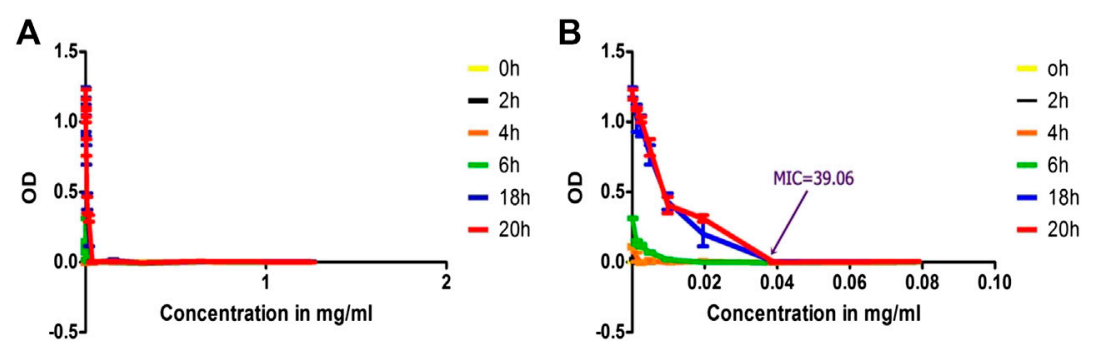

FIGURE 11 | Time-kill analysis using OD values of treated MRSA with benzyl penicillin as function of concentration, (A) throughout the range of concentration treated (1.25 to $0.002441 \mathrm{mg} / \mathrm{ml}$ ) and (B) concentration range truncated to values of 0.078125 to 0.002441$)$ to indicate MIC values clearly.

Figure 10 depicted the OD difference vs. concentration of the isolated compound at different time of incubation. The OD difference was taken between time $0 \mathrm{~h}$ and specific times of measurement. This difference sometimes became negative as result of drop in OD value of the extract solution. Stock solution prepared in DMSO formed a cloudy solution in the beginning but disappeared with increasing temperature and longer stays resulting in dropping of OD values.

Unlike the OD measurement value of the isolated solution the conventional antibiotics graph did not show significant negative values. This is because of clear solution of the antibiotics in sterile water compared to disappearing cloudy solution of the isolated compound (Figure 11).

\section{DISCUSSION}

Phytochemical screening revealed terpenoids as major components in E. kebericho extract. This is consistent with previous profiling of the EO components (Hymete et al., 2007; Tariku et al., 2011) where the Eos majorly contain terpenoids. We successfully isolated and identified dehydrocostus lactone whose spectroscopic data matched well with literatures (Taniguchi et al., 1995; Lee et al., 2014). It was the first of its kind to isolate dehydrocostus lactone from E. kebericho M. and determine its antibacterial activity though it was previously isolated from other plants (Chhabra et al., 1998; Li et al., 2005; Lee et al., 2014). Dehydrocostus lactone was previously detected from EO (Tariku 
et al., 2011) and in the smoke of the plant (Turek et al., 2016). The yield of dehydrocostus lactone $(0.5 \%)$ was greater than that of the EO $(0.18 \%)$. This could be due effectiveness of solvent extraction method compared to hydrodistillation. Hydrodistillation could damage the components and reduce the yield. This yield was less than that of Saussurea root (1.3\%) (Okugawa et al., 1996) and artemisinin (1\%) from A. annuais, which is also a sesquiterpene (Van Der Kooy and Verpoorte, 2011).

Eight strains of bacteria belonging to five species were investigated for antimicrobial susceptibility to EO and fractions of E. kebericho $M$. demonstrated a range of susceptibilities. Essential oil and ethyl acetate fraction exhibited high activity against most bacteria tested compared to other fractions. The highest antibacterial effect of ethyl acetate fraction could be attributed to the most active chemical compound/s present in the fraction. The results of previous studies (Kotzé and Eloff, 2002) were in agreement with those of the present study where extraction by different solvents showed different activities. The highest antibacterial activity of ethyl acetate fraction compared to crude extract and/or other fractions were also reported in previous studies (Gnan and Demello, 1999; Geidam et al., 2007).

Significant variation in the activity of the same fraction against strains of the same species was observed in the case of S. aureus and E. feacalis. In both cases, resistant strains were more susceptible compared to wild type. MRSA, mecA positive, was more susceptible to $\mathrm{EO}$ and ethyl acetate fraction compared to a wild type strain ATCC 29213. Similar finding was also noted with epigallocatechin Gallate b (plant extract) where S. aureus (ATCC 29213) was less susceptible compared to MRSA strains, possibly due to an increasing affinity of the extract to mutated proteins of MRSA (Betts et al., 2015). Mutation is an energy demanding, and results in increased susceptibility to a naive stress compared to a wild type. Previous studies had outlined increased overall antibiotic susceptibility to new antimicrobial agents in $S$. aureus mutants (Ling and Berger-Bächi, 1998). The increased susceptibility of mutant strains of S. aureus and E. feacalis in the current study could indicate enhanced susceptibility of mutants to a naive stress.

Gram-positive species were more susceptible to both the EO and fractions compared to Gram-negative species. Greater susceptibility of Gram-positive species compared to Gramnegative was ascribed to differences in their cell wall structures. The Gram-negative outer membranes are diffusional barriers making bacteria less susceptible to many antimicrobial agents (Ghai and Ghai, 2017). Gram-positive mutant strains were susceptible compared to wild type but more resistance was observed in Gram-negative mutant strains. This could be due to membrane alteration in gramnegatives favoring more resistance which was also shown in previous study where reduced outer membrane permeability contributed to enhanced resistance of E. coli $\mathrm{O} 157: \mathrm{H} 7$ to antimicrobial agents (Martinez et al., 2001). Gram-positive bacteria are known to be more susceptible to EO than Gramnegative bacteria. E. coli was least susceptible to EO in the present study which was consistent with the previous finding (Inouye et al., 2001). Resistance of Gram-negative bacteria was in most cases ascribed to the presence of complex resistant outer membrane (Onawunmi and Ogunlana, 1985; Mann et al., 2000).

The OD measurement worked well for MIC determination, time-kill analysis and bioactivity guided isolation. However, the concentration-OD curves at various time showed negative values in the case of isolated compound and the EO. This might mostly likely be due to turbidity change after incubation with increasing temperature. Higher concentrations of the isolated compound and the EO mixture with DMSO and water at $21 \mathrm{C}$ were more turbid and with more OD values. But after incubation at 35-37 C, the mixture gradually became clear solution which could be due to increased solubility as the temperature increased. This reduces the OD measurement from baseline values resulting in negative OD difference. This mix-up was avoided by truncating the graph around the MIC value. When truncated, the graph indicated complete growth cessation and MIC value clearly. These negative values were not observed with a standard antibiotic (penicillin-G) as they form clear solution without turbidity.

Dehydrocostus lactone, the isolated compound, was two times more potent than penicillin-G. This is the first report on the antibacterial compounds isolated from E. kebericho M. against MRSA. The potency of isolated compound was two times that of ethyl acetate fraction and four times that of the EO of the same plant. This could be due to the presence of numerous constituents that reduced the amount of the active isolated components in the mixture or increased amount of the isolated compound due to removal of the impurities. The amount of DCL in the ethylacetate fraction was $26.66 \%$. The remaining component $(74.34 \%)$ could be expected to have lesser antibacterial activity compared to the isolated compound.

Ameya and his colleagues determined the antibacterial and antifungal activities of E. kebericho crude extract. The extract demonstrated noteworthy activities against $S$. aureus, E. coli and E. faecalis (Ameya et al., 2016). The current study, however, went further and isolated the most active compound (DCL), identified and determined its antibacterial activities. In this regard, the current study could be considered the continuation of the previous study (Ameya et al., 2016). Wild type and resistant strains of the same species compared; surprisingly, the resistant (MRSA) was found to be more susceptible to the plant extract compared to the wild one.

Dehydrocostus lactone isolated from other plants showed noteworthy activities against; antibiotic-susceptible and resistant Helicobacter pylori strains (MIC $=4.0-6.7 \mu \mathrm{g} / \mathrm{ml}$ ) (Lee et al., 2014), Mycobacterium tuberculosis $\mathrm{H} 37 \mathrm{Rv}(12.5 \mu \mathrm{g} / \mathrm{ml}$ ) (LunaHerrera et al., 2007), M. tuberculosis $(2 \mu \mathrm{g} / \mathrm{ml})$, and Mycobacterium avium $(16 \mu \mathrm{g} / \mathrm{ml})$ (Cantrell et al., 1998). These activities ranges are almost similar to current findings and the little differences could be attributed to interspecies variation. Its activity decreased with the oxidized products perhaps due to decreased lipophilicity of guaianolide required for enhanced antimycobacterial activity indicating that the antibacterial activity is most likely associated to transport of guaianolide through the outer lipid layer (Cantrell et al., 1998). The antibacterial activity of highly non-polar compound could be attributed to their membrane disruptive property (Vasconcelos et al., 2018), damage to cell membrane; alter lipid profile; inhibit ATPases, cell division, membrane porins, motility, and biofilm formation; and anti- 
quorum sensing effects (Zhang et al., 2016). The findings of the current study where more non-polar fractions, EO and highly lipophilic DCL possess higher antibacterial activities could possibly indicate membrane disruptive potential.

The antibacterial activities of sesquiterpenes were mostly related to guaianolide lactone and cyclopentenone moiety (Gibbons, 2004). The guaianolide in sesquiterpene lactone showed remarkable activity against methicillin sensitive $S$. aureus (MSSA) (MIC $38 \mu \mathrm{g} / \mathrm{ml}$ ) and the activities were suggested to depend on the presence of a beta unsubstituted cyclopentenone ring moiety (Kuo-Hsiung et al., 1977). A guaianolide from Artemisia gilvescens showed excellent activities against MRSA $(\mathrm{MIC}=1.95 \mu \mathrm{g} / \mathrm{ml})$ (Kawazoe et al., 2003). Sesquiterpene curzerenone from myrrh along with other sesquiterpene mixtures showed excellent anti-staphylococcal activity ( MIC = $0.7 \mu \mathrm{g} / \mathrm{ml}$ ) (Kawazoe et al., 2003). Any modification on DCL for better activity should be made on these moieties.

The previous (Cantrell et al., 1998; Luna-Herrera et al., 2007) and the current studies showed worthy and promising antibacterial activity of DCL. However, it requires optimization to get ideal antibacterial drug hit as this has to possess higher molecular weight and increased polarity (O'Shea and Moser, 2008). Drugs with activity against only Gram-positive bacteria have much less restriction in molecular weight, especially if the target is located in the peptidoglycan matrix or on the outer surface of the underlying lipid bilayer as permeation through the inner lipid membrane is not required for the activity (O'Shea and Moser, 2008). As more activity was observed against Gram-positive compared to Gram-negative bacteria; the compound could be expected to have much less restriction in molecular weight. On the other hand, increasing the polarity of DCL reduced the activity as the activity is most likely depends on the transport through the outer lipid layer of the membrane (Cantrell et al., 1998).

Appropriate pharmacokinetic profile is crucial for improved effectiveness of a particular drug. Oral absorption of DCL was established to be good (JingZe et al., 2014; Zhang et al., 2015) but much larger peak concentration and the total amount of DCL in the body was observed with intravenous than oral administration (Peng et al., 2014). Intravenous administration might be a better route for clinical use and the compound lacks ideal antibacterial property as it shows very poor solubility in water and requires optimization for better activity. As the oral route remains the main route for the administration of herbal medicine, the bioavailability of DCL affects therapeutic effectiveness. The lead optimization for better pharmacodynamics and pharmacokinetic profile is required to be investigated. Furthermore, the safety profile and mechanism of antibacterial action of DCL should be investigated.

\section{REFERENCES}

Abdeta, D. (2016). In vitro and in vivo antitrypanosomal effects of hydromethanolic extract of Solanum anguivi fruits and Echinops kebericho roots. Master's thesis. Addis Ababa (Ethiopia): Addis Ababa University.

Abebe, D. (1996). Proceedings of the workshop on development and utilization of herbal remedies in Ethiopia. Addis Ababa, Ethiopia: Ethiopian Health and Nutrition Research Institute.

\section{DATA AVAILABILITY STATEMENT}

The original contributions presented in the study are included in the article/Supplementary Material, further inquiries can be directed to the corresponding author.

\section{ETHICS STATEMENT}

The animal study was reviewed and approved by Faculty Research Committee and approved by the Research Ethics Committee (REC) of Mbarara University of Science and Technology, Uganda. It was also registered with Uganda National Council for Science and Technology (UNCST) with reference number HS398ES.

\section{AUTHOR CONTRIBUTIONS}

SD conceived the research idea. SD and $\mathrm{DH}$ conducted antimicrobial activity study. SD and AM conducted spectroscopic analysis for isolated compound. EM, JB, and PA developed the concept, monitored and mentored the proposal development. SD wrote the draft manuscript. All authors revised, edited and approved the final manuscript.

\section{FUNDING}

This study was funded by World Bank through PharmBiotechnology and Traditional Medicine Center (PHARMBIOTRAC), African Center of Excellence II (ACE-II) Project. The funder contributed research money and stipends (SD) but was not involved in planning and implementation of the study.

\section{ACKNOWLEDGMENTS}

Part of this manuscript has been released as a pre-print at Researchsquare (Deyno et al., 2020b). We would like to thank Pharm-biotechnology and Traditional Medicine Center of Excellence (PHARMBIOTRAC) World Bank African center of excellence II (ACE-II) project for funding the research. We appreciate Casim Umba Tolo and Patrick EngueOgwang for facilitating the research fund. We would like to extend our appreciation to Médecins Sans Frontières, Epicentre Uganda for providing facility and microbial strains.

Abegaz, B. M., Tadesse, I. M., and Majinda, R. (1991). Distribution of sesquiterpene lactones and polyacetylenic thiophenes in Echinops. Biochem. Systemat. Ecol. 19, 323-328.

Abera, B. (2014). Medicinal plants used in traditional medicine by Oromo people, Ghimbi District, Southwest Ethiopia. J. Ethnobiol. Ethnomed. 10, 40. doi:10. 1186/1746-4269-10-40

Alemayehu, G. (2017). Plant diversity and ethnobotany of medicinal and wild edible plants in amaro district of southern nations, nationalities and peoples region and gelana district of oromia region, southern Ethiopia. Addis Ababa, Ethiopia: Addis Ababa University. 
Ameya, G., Gure, A., and Dessalegn, E. (2016). Antimicrobial activity of Echinops kebericho against human pathogenic bacteria and fungi. Afr. J. Tradit., Complementary Altern. Med. 13, 199-203. doi:10.21010/ajtcam.v13i6.29

Artini, M., Patsilinakos, A., Papa, R., Božović, M., Sabatino, M., Garzoli, S., et al. (2018). Antimicrobial and antibiofilm activity and machine learning classification analysis of essential oils from different mediterranean plants against pseudomonas aeruginosa. Molecules 23, 482. doi:10.3390/ molecules 23020482

Ashebir, M., and Ashenafi, M. (1999). Evaluation of the antibacterial activity of crude preparations of Zingiber officinale (zingibl), Echinops spp. (kebericho), Coriandrum sativum (dimbilal) and Cymbopogon citratus (tej sar) on some food-borne pathogens. Ethiop. J. Health Sci. 9 (1), 33-40.

Belay, G., Tariku, Y., Kebede, T., Hymete, A., and Mekonnen, Y. (2011). Ethnopharmacological investigations of essential oils isolated from five Ethiopian medicinal plants against eleven pathogenic bacterial strains. Phytopharmacology 1, 133-143. doi:10.5958/j.0975-4261.3.4.049

Betts, J. W., Sharili, A. S., Phee, L. M., and Wareham, D. W. (2015). In vitro activity of epigallocatechin gallate and quercetin alone and in combination versus clinical isolates of methicillin-resistant Staphylococcus aureus. J. Nat. Prod. 78, 2145-2148. doi:10.1021/acs.jnatprod.5b00471

Bitew, H., and Hymete, A. (2019). The genus Echinops: phytochemistry and biological activities: a review. Front. Pharmacol. 10, 1234. doi:10.3389/fphar. 2019.01234

Cantrell, C. L., Nuñez, I. S., Castañeda-Acosta, J., Foroozesh, M., Fronczek, F. R., Fischer, N. H., et al. (1998). Antimycobacterial activities of dehydrocostus lactone and its oxidation products. J. Nat. Prod. doi:10.1021/np970333i

Chhabra, B. R., Gupta, S., Jain, M., and Kalsi, P. S. (1998). Sesquiterpene lactones from Saussurea lappa. Phytochemistry 49, 801-804.

CLSI (2018). Methods for dilution antimicrobial susceptibility tests for bacteria that grow aerobically. Albany, NY: National Committee for Clinical Laboratory Standards.

da Silva, L. C. N., da Silva, M. V., and Correia, M. T. (2017). New Frontiers in the search of antimicrobials agents from natural products. Front. Microbiol. 8, 210. doi:10.3389/fmicb.2017.00210

Debella, A., Taye, A., Abebe, D., Mudi, K., Melaku, D., and Taye, G. (2007). Screening of some Ethiopian medicinal plants for mosquito larvicidal effects and phytochemical constituents. Pharmacol. Online 3, 231-243.

Desta, B. (1993). Ethiopian traditional herbal drugs. Part II: antimicrobial activity of 63 medicinal plants. J. Ethnopharmacol. 39, 129-139. doi:10.1016/03788741(93)90028-4

Deyno, S., Abebe, A., Tola, M. A., Hymete, A., Bazira, J., Makonnen, E., et al. (2020a). Acute and sub-acute toxicity of Echinops kebericho decoction in rats. BMC Complement. Med. Ther. 20, 2. doi:10.1186/s12906-019-2794-z

Deyno, S., Hope, D., Bazira, J. P., Makonnen, E., and Alele, P. E. (2020b). Antibacterial activities of essential oil and fractions of ethanolic extract of Echinops kebericho tuber. Research Square. doi:10.21203/rs.2.23243/v1

Dorman, H. J., and Deans, S. G. (2000). Antimicrobial agents from plants: antibacterial activity of plant volatile oils. J. Appl. Microbiol. 88, 308-316. doi:10.1046/j.1365-2672.2000.00969.x

Eloff, J. N. (1998). A sensitive and quick microplate method to determine the minimal inhibitory concentration of plant extracts for bacteria. Planta Med. 64, 711-713. doi:10.1055/s-2006-957563

Elshikh, M., Ahmed, S., Funston, S., Dunlop, P., McGaw, M., Marchant, R., et al. (2016). Resazurin-based 96-well plate microdilution method for the determination of minimum inhibitory concentration of biosurfactants. Biotechnol. Lett. 38, 1015-1019. doi:10.1007/s10529-016-2079-2

Geidam, Y. A., Ambali, A. G., and Onyeyili, P. A. (2007). Phytochemical screening and antibacterial properties of organic solvent fractions of Psidium guajava aqueous leaf extracts. Int. J. Pharmacol. 3 1, 68-73. doi:10.3923/ijp.2007.68.73

Ghai, I., and Ghai, S. (2017). Exploring bacterial outer membrane barrier to combat bad bugs. Infect. Drug Resist. 10, 261. doi:10.2147/IDR.S144299

Gibbons, S. (2004). Anti-staphylococcal plant natural products. Nat. Prod. Rep. 21 (2), 263-277. doi:10.1039/b212695h

Gnan, S. O., and Demello, M. T. (1999). Inhibition of Staphylococcus aureus by aqueous Goiaba extracts. J. Ethnopharmacol. 68, 103. doi:10.1016/S03788741(99)00048-3

Hammer, K. A., Carson, C. F., and Riley, T. V. (2012). Effects of Melaleuca alternifolia (tea tree) essential oil and the major monoterpene component terpinen-4-ol on the development of single- and multistep antibiotic resistance and antimicrobial susceptibility. Antimicrob. Agents Chemother. 56, 909-915. doi:10.1128/AAC.05741-11

Holmstrup, P., and Klausen, B. (2018). The growing problem of antimicrobial resistance. Oral Dis. 24, 291-295. doi:10.1111/odi.12610

Hymete, A., and Afifi, M. S. (1997). Investigation of the fixed oil isolated from the roots of Echinops kebericho Mesfin. Mansoura. J. Pharmacol. Sci. 13, 59-69.

Hymete, A., and Kidane, A. (1991). Screening for anthelmintic activity in two Echinops spp. Ethiop. Pharmaceut. J. 9, 67-71.

Hymete, A., Rohloff, J., Iversen, T., and Kjøsen, H. (2007). Volatile constituents of the roots of Echinops kebericho Mesfin. Flavour Fragrance J. 22, 35-38. doi:10. $1002 / f f j .1746$

Inouye, S., Takizawa, T., and Yamaguchi, H. (2001). Antibacterial activity of essential oils and their major constituents against respiratory tract pathogens by gaseous contact. J. Antimicrob. Chemother. 47, 565-573. doi:10.1093/jac/47. 5.565

Ivana, T. (2015) Phytochemische und antimikrobielle Untersuchung an Echinops kebericho Mesfin. Master's thesis. Graz (Austria): Karl-Franzens-Universität Graz. doi:10.13140/RG.2.1.2083.2084

Jemberie, W., Tadie, A., Enyew, A., Debebe, A., and Raja, N. (2016). Repellent activity of plant essential oil extracts against malaria vector Anopheles arabiensis Patton (Diptera: Culicidae). ENTOMON 41 (2), 91-98.

JingZe, Z., Xiao, H., WenYuan, G., Zhuo, Q., HuiMin, G., Zhen, L., et al. (2014). Pharmacokinetic study on costunolide and dehydrocostuslactone after oral administration of traditional medicine Aucklandia Lappa Decne. by LC/MS/ MS. J. Ethnopharmacol. 151 (1), 191-197. doi:10.1016/j.jep.2013.10.024

Kawazoe, K., Tsubouchi, Y., Abdullah, N., Takaishi, Y., Shibata, H., Higuti, T., et al. (2003). Sesquiterpenoids from Artemisia g Ilvescens and an anti-MRSA compound. J. Nat. Prod. 66 (4), 538-539. doi:10.1021/np020593m

Kloos, H. (1977). Preliminary studies of medicinal plants and plant products in markets of central Ethiopia. Ethnomedizin. e4, 63-102

Kotzé, M., and Eloff, J. N. (2002). Extraction of antibacterial compounds from Combretum microphyllum (Combretaceae). South Afr. J. Bot. 68 1, 62-67, doi:10.1016/s0254-6299(16)30456-2

Lee, H. K., Song, H. E., Lee, H. B., Kim, C. S., Koketsu, M., Ngan, L. T., et al. (2014). Growth inhibitory, bactericidal, and morphostructural effects of dehydrocostus lactone from magnolia sieboldii leaves on antibiotic-susceptible and -resistant strains of helicobacter pylori. PLoS One, 9, e95530. doi:10.1371/journal.pone.0095530

Li, A., Sun, A., and Liu, R. (2005). Preparative isolation and purification of costunolide and dehydrocostuslactone from Aucklandia lappa Decne by high-speed counter-current chromatography. J. Chromatogr. A 1076, 193-197. doi:10.1016/j.chroma.2005.04.042

Ling, B., and Berger-Bächi, B. (1998). Increased overall antibiotic susceptibility in Staphylococcus aureus femAB null mutants. Antimicrob. Agents Chemother 42, 936-938. doi:10.1128/AAC.42.4.936

Luna-Herrera, J., Costa, M. C., González, H. G., Rodrigues, A. I., and Castilho, P. C. (2007). Synergistic antimycobacterial activities of sesquiterpene lactones from Laurus Spp. J. Antimicrob. Chemother. doi:10.1093/jac/dkl523

Mann, C. M., Cox, S. D., and Markham, J. L. (2000). The outer membrane of Pseudomonas aeruginosa NCTC 6749 contributes to its tolerance to the essential oil of Melaleuca alternifolia (tea tree oil). Lett. Appl. Microbiol. 30, 294-297. doi:10.1046/j.1472-765x.2000.00712.x

Martinez, M. B., Flickinger, M., Higgins, L., Krick, T., and Nelsestuen, G. L. (2001). Reduced outer membrane permeability of Escherichia coli O157:H7: suggested role of modified outer membrane porins and theoretical function in resistance to antimicrobial agents. Biochemistry 40, 11965-11974. doi:10. 1021/bi0109515

Megersa, M., Jima, T. T., and Goro, K. K. (2019). The use of medicinal plants for the treatment of toothache in Ethiopia. Evid. Based Complement Alternat. Med. 2019, 2645174. doi:10.1155/2019/2645174

Okugawa, H., Ueda, R., Matsumoto, K., Kawanishi, K., and Kato, A. (1996). Effect of dehydrocostus lactone and costunolide from Saussurea root on the central nervous system in mice. Phytomedicine, 3, 147. doi:10.1016/S0944-7113(96)80028-6

Onawunmi, G. O., and Ogunlana, E. O. (1985). Effects of lemon grass oil on the cells and spheroplasts of Escherichia coli NCTC 9001. Microbios Lett. 28, 63-68. doi:10.1016/j.rvsc.2011.01.012

O'Shea, R., and Moser, H. E. (2008). Physicochemical properties of antibacterial compounds: implications for drug discovery. J. Med. Chem. 51 (10), 2871-2878. doi:10.1021/jm700967e 
Patel, B. P., Cockerill, F. R., Bradford, P. A., Eliopoulos, G. M., Hindler, J. A., and Jenkins, S. G. (2015). M07-A10 methods for dilution antimicrobial susceptibility tests for bacteria that grow aerobically; approved standard. 10th Edn. Wayne, PA: Clinical and Laboratory Standards Institute.

Peng, Z., Wang, Y., Gu, X., Guo, X., and Yan, C. (2014). Study on the pharmacokinetics and metabolism of costunolide and dehydrocostus lactone in rats by HPLC-UV and UPLC-Q-TOF/MS. Biomed. Chrom. 28 (10), 1325-1334. doi:10.1002/bmc.3167

Porras, G., Chassagne, F., Lyles, J. T., Marquez, L., Dettweiler, M., Salam, A. M., et al. (2020). Ethnobotany and the role of plant natural products in antibiotic drug discovery. Chem. Rev. doi:10.1021/acs.chemrev.0c00922

Salehi, B., Konovalov, D. A., Fru, P., Kapewangolo, P., Peron, G., Ksenija, M. S., et al. (2020). Areca catechu-from farm to food and biomedical applications. Phyther. Res. 34 (9), 2140-2158. doi:10.1002/ptr.6665

Salehi, B., Selamoglu, Z., Sener, B., Kilic, M., Jugran, A. K., De Tommasi, N., et al. (2019a). Berberis plants-drifting from farm to food applications, phytotherapy, and phytopharmacology. 8 (10), 522.doi:10.3390/foods8100522

Salehi, B., Sener, B., Kilic, M., Sharifi-Rad, J., Naz, R., Yousaf, Z., et al. (2019b). Dioscorea plants: a genus rich in vital nutra-pharmaceuticals-a review. J. Pharm. Res 18 (Suppl1), 68-89. doi:10.22037/ijpr.2019.112501.13795

Schneider, E. K., Reyes-Ortega, F., Velkov, T., Li, J., and Li, J. 2017. Antibiotic-nonantibiotic combinations for combating extremely drug-resistant Gram-negative "superbugs", Essays Biochem. 61, 115. doi:10.1042/EBC20160058

Taniguchi, M., Kataoka, T., Suzuki, H., Uramoto, M., Ando, M., Arao, K., et al. (1995). Costunolide and dehydrocostus lactone as inhibitors of killing function of cytotoxic T lymphocytes. Biosci. Biotechnol. Biochem. 59, 2064-2067. doi:10. 1271/bbb.59.2064

Tariku, Y., Hymete, A., Hailu, A., and Rohloff, J. (2011). In vitro evaluation of antileishmanial activity and toxicity of essential oils of Artemisia absinthium and Echinops kebericho. Chem. Biodivers 8, 614-623. doi:10.1002/cbdv. 201000331

Teklehaymanot, T., and Giday, M. (2007). Ethnobotanical study of medicinal plants used by people in Zegie Peninsula, Northwestern Ethiopia. J. Ethnobiol. Ethnomed. 3, 12. doi:10.1186/1746-4269-3-12

Teklehaymanot, T., Giday, M., Medhin, G., and Mekonnen, Y. (2007). Knowledge and use of medicinal plants by people around Debre Libanos monastery in Ethiopia. J. Ethnopharmacol, 111, 271. doi:10.1016/j.jep.2006.11.019
Toma, A., Deyno, S., Fikru, A., Eyado, A., and Beale, A. (2015). In vivo antiplasmodial and toxicological effect of crude ethanol extract of Echinops kebericho traditionally used in treatment of malaria in Ethiopia. Malar. J. 14, 196. doi:10.1186/s12936-015-0716-1

Turek, I., Carvalho, S. R., Wube, A., and Bucar, F. (2016). "Headspace analysis of the smoke of Echinops kebericho Mesfin," in Trends in natural products research-PSE young scientists meeting, Pulawy, Poland, May, 2016.

Van Der Kooy, F., and Verpoorte, R. (2011). The content of artemisinin in the artemisia annua tea infusion. Planta Med. (15), 1754-1756, doi:10.1055/s-0030-1271065

WHO (2017). World health organization releases global priority list of antibioticresistant bacteria to guide research, discovery, and development of new antibiotics. Mumbai, India: Medknow Publications.

Yang, S.-K., Low, L.-Y., Yap, P. S.-X., Yusoff, K., Mai, C.-W., Lai, K.-S., et al. (2018), Plant-derived antimicrobials: insights into mitigation of antimicrobial resistance. Record Nat. Prod. 12 (4), 295-396. doi:10.25135/rnp.41.17.09.058

Yigezu, Y., Haile, D. B., and Ayen, W. Y. (2014). Ethnoveterinary medicines in four districts of Jimma zone, Ethiopia: cross sectional survey for plant species and mode of use. BMC Vet. Res. 10, 76. doi:10.1186/1746-6148-10-76

Zhang, J., Wang, L., Jin, Z., Qu, Z., Chen, Y., and Gao, W. (2015). Pharmacokinetics study on costunolide and dehydrocostuslactone after administration of traditional Chinese medicine Weichang'an Pills. Zhongguo Zhong Yao Za Zhi. doi:10.4268/cjcmm20150635

Zhang, Y., Liu, X., Wang, Y., Jiang, P., and Quek, S. (2016). Antibacterial activity and mechanism of cinnamon essential oil against Escherichia Coli and Staphylococcus Aureus. Food Control. doi:10.1016/j.foodcont.2015.05.032

Conflict of Interest: The authors declare that the research was conducted in the absence of any commercial or financial relationships that could be construed as a potential conflict of interest.

Copyright (๑) 2021 Deyno, Mtewa, Hope, Bazira, Makonnen and Alele. This is an open-access article distributed under the terms of the Creative Commons Attribution License (CC BY). The use, distribution or reproduction in other forums is permitted, provided the original author $(s)$ and the copyright owner(s) are credited and that the original publication in this journal is cited, in accordance with accepted academic practice. No use, distribution or reproduction is permitted which does not comply with these terms. 